pumps to make them quite secure against the most extensive damage to their bottoms. Indeed, as regards the stoke-holds, they are already fitted with the air-tight hatches in order to be able to used forced draught for the furnaces. Modern merchant ships are built with an iron deck, so that there is no difficulty about providing the strength. Their hatchways are, however, always very large; but, on the other hand, there is little traffic through them, so that they could be treated in a more substantial way than the smaller hatchways of a man-of-war with her large complement of men. The bulkheads which subdivide the hold into compartments always profess to be water-tight, and to be able to resist the pressure exercised by the water filling the compartment. There should therefore be no difficulty about them. Indeed, if ships were built to withstand air pressure, a very simple method would be provided for testing the efficiency of the bulkheads without the disagreeable process of filling the compartment with water. It would be only necessary to close the legitimate openings and get the air in it up to a pressure equal to that of the ship's draught of water, and the result would be unequivocal. It is proper to observe that the construction of an air-tight bulkhead would differ slightly from that of a water-tight bulkhead, inasmuch as it will be exposed to the maximum pressure over its whole surface, whereas the water-tight bulkhead is exposed to a graduated pressure, being greatest at the keelson, and least under the deck.

A further advantage of fitting a ship with air-tight subdivisions is, that it not only gives her greater security against foundering, but it affords a means of largely insuring her against risks of fire. This has more especial reference to merchant ships. If the contents of a ship's hold catch fire, the easiest way of putting it out is to stop the supply of air, and this can be done if the hold is air-tight.

So far the damage to the ship is supposed to be a rent in the bottom. If it is not in the bottom, but somewhere above it, then the air can only expel the water down to the level of the breach, when the air will begin to escape through its uppermost part. It will now depend on the supply of forced air available, how large a hole can be kept continuously filled by a stream of air rushing out. The area so occupied is necessarily closed to the entrance of water, and if the machinery can supply air at a sufficient rate, the whole rent can be filled by a current of air, which, so long as it is kept up, is as efficient a leak stopper as a plate of iron would be, and meantime the bottom of the hold can be cleared by the ordinary bilge pumps.

Rents in a ship's side, such as are produced when she is run down, or rammed by another, are usually so extensive and serious that, unless the ship is protected by an inner skin, immediate destruction ensues before there is time to take any measures for rescuing her. But with an inner skin the damage may be so far reduced as to make it possible to deal with it as above indicated. The higher up on the ship's side is the damage the less suitable is the pneumatic method for dealing with it, if it is of a really extensive character ; but, on the other hand, the more easy is it (given the time) to get at it, and deal with it from the outside. In all cases where the ship has been damaged by touching the ground, or by torpedo explosion under the bottom, and not involving the destruction of the ship, the pneumatic method affords the readiest means of combating the results.

It must be remembered that a ship's hold when filled with compressed air will be habitable; that is, if an air lock is provided, men can descend into it and repair the damage, just as they can descend into a caisson and dig out the foundations for the pier of a bridge.

The pneumatic method is however not only adapted for keeping damaged vessels afloat, it is also useful for raising sunken or stranded ships. For this purpose the salvage steamer must be provided with air-forcing pumps as well as the suction pumps which she usually carries. Having closed, and if necessary strengthened the deck, by means of divers if below water, she then pumps air into the holds of the ship, and at once restores a large proportion of her original buoyancy to her. If she does not rise, the other methods of salvage can be applied in addition, and with much increased chance of success.

The principle of this method is not new. A very old device in endeavouring to float, or to keep afloat, ships, is to fill as much of their damaged hold as possible with empty casks. A later modification of this method is to use inflatable india-rubber bags. It may be remembered that after the Vanguard sank Admiral Popoff of the Russian Navy sent a large apparatus of this kind in order to render assistance in trying to float her. Both these appliances are cumbersome: A ship's hold is seldom quite empty when she sinks, and even if it were, it is not easy to fill it under water with casks full of air, or even with inflatable air bags; and in any case it is difficult in this way to fill more than a fraction of the hold with air. The simple and efficient way of dealing with the matter is to treat the ship's hold itself as the vessel to be filled with air.

Compressed air is every day occupying a wider field as a means of transmitting power. It is already used as a substitute for gunpowder in the guns for firing shells with high explosives. It seems to me that if it can be used for largely increasing the safety of life and property at sea it is right that the fact should be brought as prominently forward as possible, in the hope that it may receive practical application in the hands of the shipbuilder and the engineer. J. Y. BUCHANAN.

\section{NOTES ON STANLEY'S JOURNEY.}

I HAVE watched every footstep of Stanley for the past twenty years, had constant intercourse with him during his short visits to this country, and have unbounded confidence in him as a pioneer, for I cannot but admire the noble efforts he has made to open up Africa to civilization. Wherever he has travelled he has left his mark behind him; others may follow his example without fear of being molested, and he has given us such vivid descriptions of the regions mapped by him that, for all practical purposes, no traveller need supervise his work. Some say he has been too high-handed with the natives, but I may be allowed to think that his power of influencing those over whom he holds command has proved him to be the most trusted and successful traveller of the age. If his explorations be quickly and judiciously followed up, the native inhabitants will feel security against all oppression, and the traders in slaves will be expelled from the country.

Brilliant is scarcely the name to give the exploit of Mr. Stanley, as given in his recently published letters. What instance in travel can excel such devotion? Is there a schoolboy who does not admire a man with his indomitable pluck and dogged perseverance? His latest journey to relieve Emin Pasha has outstripped, if possible, all his previous explorations in the "Dark Continent." Those I6o days of toil, from June 28 to December I2, I888, through starvation, desertion, mutiny, savage dwarfs and cannibals, thorny thickets, darkness, and swamps, were enough to try the patience of any human being; but, thank God, his British pluck never failed him; on and on he pressed, while his native followers were in utter despair, and broke out into mutiny. He used every persuasion with them : all failed. What was he to do? He felt that his duty was to relieve Emin Pasha-his countrymen expected this - and, with his accustomed sense of what was just and right, the two ringleaders of the mutinous band 
were hung in the presence of his camp followers. This wholesome example proved to be the saving of his expedition. He emerged from the poisoned atmosphere of the forest, and says that he was amply rewarded when his remaining native followers kissed his hands in grateful acknowledgment of being delivered from death.

The party proceeded on, moving with great glee across the grassy slope amidst villages and cultivation, soon standing upon the brink of the crags which overhang the western shores of the Albert Nyanza of Baker. Here fresh difficulties arose; the suspicious natives would give them no canoes, would hold no intercourse with him. Emin Pasha's steamer was not in sight, and, after consulting his officers, Stanley retired to an entrenched position, sent Stairs, R.E., for his English-built boat, and, terrible though this journey has been in every form, the heroic Stanley won his point, and shook hands with Emin Pasha on April 29, 1888, 465 days after leaving Charing Cross to his relief.

It is quite possible that he may return to England by the end of May, but there are several reasons which may delay him. The difficulty of providing for so large a party as ten thousand followers belonging to Emin Pashathis is a most anxious charge. Again, Stanley's thirst to solve the problem of the unexplored country south of the Albert Lake may lead him there, and I really feel more anxious about him since the arrival of his letters than I felt before we heard of his safety, for he is so fearless, he never sees a difficulty.

The marvellous growth of vegetation upon Stanley's route is not to be wondered at, as we know that in similar latitudes, such as Uganda, Borneo, and the Amazon, the same density of undergrowth and forest exists. A band of moisture encompasses the world at the equator, extending three to four degrees of latitude on either side; the vertical rays of the sun beat down with great intensity, and vegetation is almost seen to grow. In Uganda I have seen the banana trees, after being felled, shoot up from their centres immediately after their stems had been cut across; the roots of the trees are surrounded by spongy soil laden with moisture from the daily fall of misty rain, and the powerful sun completes the formation of the great forests of banana trees, without the aid of cultivation, beyond the help of the decayed leaves. We see the same process in the great belt of forest called in India the "Terai," which extends along the bases of the southern spurs of the Himalayas. Here the rains which fall upon these spurs, ooze out over the lands of the "Terai" and feed the roots of the magnificent forest trees, forming food and shelter for the wild elephant, boar, and swamp-loving creatures; but the atmosphere is almost certain death to all human beings except the inhabitants. We cannot, therefore, feel any surprise that Stanley and all his party suffered from sickness, and wonder how any of them escaped alive.

"Ugarrowa or Ulede Balyuz, a tent-boy of Speke's," an "Arab slave-dealer," is constantly mentioned in Stanley's interesting narrative. I am able to give some information about this person if he be the same "Ulede," one of "Speke's faithfuls," represented in the Illustrated London Neres of July 4, 1863, as "Ulede Senior," in a photograph taken by Royer in Cairo. He told me that he was a rative of Uhiao, was captured by the Watuta in infancy, and sold as a slave to a Zanzibar trader. He was engaged by Speke as a load carrier, and became my valet, which he continued to be till our arrival in Cairo. He was thoroughly trustworthy, as many of his race are, and more intelligent than most of our men. He could name accurately every march in our journey, most of the trees and plants, and could tell a capital story. His career has been deservedly successful, and though from circumstances he has become a well-known dealer in slaves, I might ask what career is open to any young man of African origin who has never received the slightest edu- cation. Ulede Balyuz (i.e. the Consul's boy) has done good service in sheltering Stanley's sick, and in transmitting the graphic despatches which we have all read with profound interest, therefore he ought not to be condemned too hastily, but rather be utilized by the Congo Free State Government as the head of a district.

The dwarfs mentioned by Stanley must be very numerous, as he came upon one hundred and fifty villages of them. One specimen alone was seen by Speke and myself in Unyoro, and at least one perfect skeleton has been received from Emin Pasha by Prof. Flower. They seem very proficient in hunting, and used every conceivable device to poison the men of Stanley's party by placing. staked pitfalls on the path, in the manner they would trap an elephant or antelope, and it appears they were only too successful.

We must wait for Stanley's return to hear more of the race of Manyema. I believe this race to be the NyamNyam described thirty years ago by Mr. Petherick, but without knowing their tribal marks and arms, this cannot be decided. Meantime, these daring cruel savages have shot down poor Major Barttelot, and are engaged by the slave-dealers of Zanzibar to plunder, capture, and kill the inhabitants, and reduce the country to a wilderness; so that, through Stanley's brave deeds, we have our work of civilization before us.

\section{FURTHER NOTES ON THE GEOLOGY OF THE EASTERN COAST OF CHINA AND THE ADJACENT ISLANDS.}

TWO years ago some notes were published in NATURE (vol. xxxvi. p. 163) on the geology of a portion of the coast of China, compiled from a report forwarded by Surgeon P. W. Bassett-Smith, R.N., of H.M.S. Rambler, to the Hydrographical Department of the Admiralty. Since then Mr. Bassett-Smith has extended the area of his investigations both to the north and south of the coast-line dealt with in this report, so as to embrace the whole eastern coast from Shanghai and Hong Kong ; and has embodied his observations in two further reports to the Hydrographical Department. These documents, with the specimens referred to in them, having been submitted by the Hydrographer to the Director-General of the Geological Survey, Dr. Hatch, of the Petrographical Department of the Survey, has drawn up the following abstract of the reports and notes regarding the specimens :-

Speaking generally, the whole coast between Shanghai and Hong Kong consists of granite ; the high mountainranges, especially in the south, present chiefly this rock. Flanking the granite on various parts of the coast are vast masses of crystalline schists (gneiss, mica-schist, \&c.), parts of which are rich in metallic ores, even auriferous quartz occurring, as at Chinsan, and more plentifully in the Shangtung province, where it is profitably worked by the Chinese. A curious conglomerate, found at Sharp. Point Islands, River Min, at Davis Island, Yangtsekiang, and also in the Shangtung province, is overlain by slates, probably of Cambrian age, but for the most part unfossiliferous, although some fish-remains and Algæ have been found in the Shangtung province.

In the northern part of the coast (Chusan to Shanghai), there are many traces of ancient volcanic activity. Th? older volcanic rocks consist of porphyritic felsites (Chınsan Island, Davis Island, Elliot Island, Bonham Island, and Side Saddle Island) and basalts (Changtau), both of which are intrusive in the granite and crystalline schists. More recent volcanic tuffs and breccias were obtained in a quarry near Ningpo.

The Chusan Archipelago.-Of this group of islands, situated at the mouth of Hang-chow Bay, south of Shanghai, the northern members have a marked vol- 